Paolo Flezzani MD, Michael J. Alvis MD, J.R. Jacobs, PHD, M.M. Schilling MT (ASCP), S. Bai, PH D, J.G. Reves MD

\title{
Sufentanil disposition during cardiopulmonary bypass
}

\begin{abstract}
In order to investigate the ability of a computer-assisted continuous infusion (CACI) system to maintain constant plasma levels of sufentanil during cardiopulmanary bypass (CPB) using pharmacokinetic data derived from healthy surgical patients to determine the infusion rate, ter patients were anaesthetized with diazepam, enflurane and oxygen until ten minutes prior to the expected time of initiation of CPB. Ar that point, an infusion of sufentanil, aimed to reach a central compartment concentration of $5 \mathrm{ng} \cdot \mathrm{ml}^{-1}$, was started via CACI. Plasma concentrations of sufentanil, haematocrit, total protein and albumin concentrations, and nasopharyngeal and CPB inflow temperatures were ottained at predetermined intervals before and up to $90 \mathrm{~min}$ after the initiation of CPB. Plasma concentrations of sufentanil reached $3.8 \pm 0.4 \mathrm{ng}^{\prime} \mathrm{ml}^{-1}$ before $\mathrm{CPB}$ and approached the $5.0 \mathrm{ng} \cdot \mathrm{ml}^{-1}$ set point $\left(4.7 \pm 0.4 \mathrm{ng} \cdot \mathrm{ml}^{-1}\right.$, over the 90 min of CPB. In conclusion, our results show that it is possible to obtain stable plasma levels of sufentanil on CPB using a pharmacokinetically driven infusion scheme; however, our data suggess that use of such a system may lead to accumulation of drug during $C P B$
\end{abstract}

\section{Key words}

ANAESTHETIC TECHNIQUE: COMputerized; ANAESTHESIA: cardiac; ANAESTHETICS: INTRA VENOUS; sufentanil, continuous infusion; sURGERY: cardiac; cardiopulmonary bypass.

From the Division of Cardiothoracic Anesthesia, Department of Anesthesiology, Duke University Medical Center, Durham, North Carolina, and the School of Veterinary Medisine, North Carolina State University, Raleigh, North Carolina.

Address correspondence to: Dr. J.G. Reves, Division of Cardiothoracic Anesthesia, P.O. Box 3094, Duke University Medical Center, Durham, NC 27710
The institution of cardiopulmonary bypass (CPB) causes profounds changes in the pharmacokinetics of most drugs, leading to unpredictable plasma levels and possibly to unpredictable effects. It may be important to the anaesthetist to develop the ability to either maintain stable plasma levels or change them to new but predictable plasma levels of intravenous anaesthetic agents during cardiac surgery with hypothermic CPB.

The purpose of this study was to investigate the ability of a pharmacokinetically-driven computer-assisted continuous infusion (CACl) system to maintain a stable and prcdictcd plasma level of sufentanil during hypothermic $\mathrm{CPB}$.

The $\mathrm{CACl}$ system used in this investigation has been used in the maintenance of fentanyl anaesthesia before $\mathrm{CPB}$ in patients undergoing coronary revascularization.' In this initial report, $\mathrm{CACI}$ was effective and accurate in closely approaching the set central compartment concentrations whether it was used to maintain a fixed concentration or to vary concentrations according to the clinical judgement of the anaesthetist.

\section{Methods}

After institutional approval, ten patients scheduled for elective primary coronary revascularization gave informed consent and were entered into this study. Mean \pm SD age was $61 \pm 11$ yr (range 39-75), and the preoperative left ventricular function was good (mean $\pm S D$ angiographic ejection fraction $=0.51 \pm 0.1$ ). Preoperative betaadrenergic and calcium entry blocking medications were given on the day of surgery.

All patients were premedicated with lorazepam 0.02 $\mathrm{mg} \cdot \mathrm{kg}^{-1} \mathrm{PO}$ and morphine $0.1 \mathrm{mg} \cdot \mathrm{kg}^{-1}$ IM $60-90 \mathrm{~min}$ before the expected time of induction. After arrival in the induction room, standard monitoring systems consisting of a five lead ECG, a radial artery catheter and a thermodilution pulmonary artery cathetcr were inscrted.

General anaesthesia was induced with diazepam $\left(0.5 \mathrm{mg} \cdot \mathrm{kg}^{-1}\right)$ and pancuronium $\left(0.1 \mathrm{mg} \cdot \mathrm{kg}^{-1}\right)$, and was maintained with enflurane $(0-2$ per cent inspired concentrations) and oxygen (100 per cent). Ten minutes before the expected beginning of CPB, a computer-assisted continuous infusion of sufentanil set to reach and maintain a central compartment concentration of $5 \mathrm{ng}^{\prime} \mathrm{ml}^{-1}$ was 
started. Arterial blood samples for sufentanil levels were obtained prior to the beginning of the infusion (control), five and ten minutes after the beginning of the infusion, immediately prior to the initiation of CPB, and $2,5,10$, $15,20,25,30,45,60$ and 90 min after the initiation of CPB. Blood samples for measurement of haematocrit (HCT), total protein concentration (TP), albumin concentration (ALB), and $\mathrm{pH}$ were obtained at control, prior to $\mathrm{CPB}$, at 5, 30, 45 and $90 \mathrm{~min}$ on CPB. Nasopharyngeal temperature (NPT) was measured at the same time intervals, and inflow temperature (IT), defined as the temperature measured in the arterial limb of the extracorporeal circulation system, was measured during CPB.

Sufentanil plasma levels were measured by radioimmunoassay. ${ }^{2}$ Sensitivity of the assay was $0.1 \mathrm{ng} \cdot \mathrm{ml}^{-1}$; samples were measured in duplicate and the intra- and inter-assay coefficients of variation were on average 5 and 6.2 per cent. Replicate analyses of control plasma samples. covering the therapeutic range of concentrations, yielded relative errors below ten per cent for each concentration.

Statistical analysis was performed using analysis of variance and paired t test. Differences with $p \leq 0.05$ were considered to be significant.

The CACI system used in this study has been described previously.' It employs an open three-compartment pharmacokinetic model which allows the design of an infusion scheme to achieve and maintain constant plasma levels of the drug being infused. The rate constants $(\mathrm{k} 10, \mathrm{k} 12$, etc.) and the volume of the central compartment ( $\mathrm{Vc}$ ) used in the infusion equation were obtained from published data. ${ }^{3}$ The three compartment coefficients used in this study were $V_{c}=0.164 \mathrm{~L} \cdot \mathrm{kg}^{-1}, \mathbf{k} 10=0.089, \mathrm{k} 31=0.01$, $\mathrm{k} 13=0.077, \mathrm{k} 21=0.161$ and $\mathrm{k} 12=0.35$.

\section{Results}

Sufentanil plasma levels (Figure) reached $3.8 \pm 0.4$ $\mathrm{ng} \cdot \mathrm{ml}^{-1}$ immediately before initiation of $\mathrm{CPB}$, feil to 2.5 $\pm 0.3 \mathrm{ng} \cdot \mathrm{ml}^{-1}$ upon initiation of CPB and slowly rose to $4.7 \pm 0.4 \mathrm{ng} \cdot \mathrm{ml}^{-1}$, approaching the set point $(5.0$ $\mathrm{ng} \cdot \mathrm{ml}^{-1}$ ) towards the end of CPB. Changes in plasma levels at 2, 5, 60 and 90 min on $\mathrm{CPB}$ were significant compared to pre-CPB levels; in addition, sufentanil plasma levels at $10,15,20,25,45,60$ and $90 \mathrm{~min}$ on CPB were significantly different from the plasma level measured after 2 min on CPB. Haematocrit, total protein and albumin concentration and nasopharyngeal temperature are in the table. Haematocrit (Hct) decreased significantly (30 per cent), TP and ALB decreased about 20 per cent with the institution of $\mathrm{CPB}$, but remained stable during the course of CPB. NPT decreased significantly during CPB, reaching its lowest value $\left(27^{\circ} \mathrm{C}\right) 45 \mathrm{~min}$ after the initiation of CPB. Plasma sufentanil levels correlated weakly with

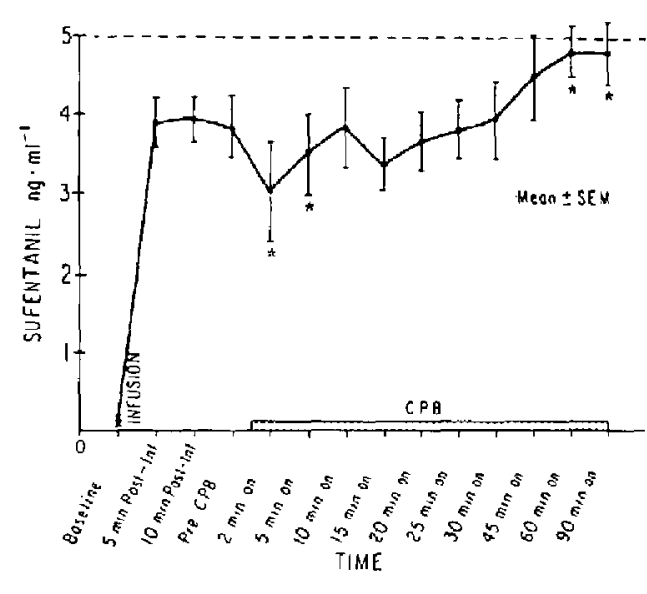

FIGURE Sufentanil plasma levels achieved by the computerized infusion before and during cardiopulmonary bypass (CPB). The setpoint sufentanil level was $5 \mathrm{ng} \cdot \mathrm{ml} \quad{ }^{\prime} .{ }^{*} p<0.05$ vs initial value $(5 \mathrm{~min}$ after start of infusion).

Hct before CPB but not during CPB. There was a trend towards an inverse relation between sufentanil plasma levels and NPT at 20 min on CPB and at 25 min on CPB when mean NPT were 30.5 and $29.5^{\circ} \mathrm{C}$ respectively. Similarly, plasma sufentanil levels and inflow temperature in the extracorporeal circulation system showed a tendency to an inverse relation at $15 \mathrm{~min}, 20 \mathrm{~min}$ and at 25 min when inflow temperatures were respectively $27 \pm 2$, $28 \pm 2$ and $28 \pm 2^{\circ} \mathrm{C}$. There was no correlation between sufentanil levels and either TP or ALB levels.

\section{Discussion}

The institution of CPB affects the pharmacokinetics of most drugs in multiple ways. Hypotension, hypothermia, haemodilution, lung isolation, heparinization, pulsatile flow, hormonal changes and blood flow redistribution can each alter the northal pharmacokinetics of drugs. ${ }^{4}$ In particular, the volume of distribution of most drugs

TABLE Haematocrit, total protein, albumin and nasopharyngeal temperature (mean \pm SEM)

\begin{tabular}{lllll}
\hline & Hct $(\%)$ & $T P\left(g \cdot m I^{-1}\right)$ & $A L B\left(n m \cdot d l^{-1}\right)$ & $\left.N T \mathrm{r}^{\circ} \mathrm{C}\right)$ \\
\hline Control $(\mathrm{C})$ & $36 \pm 2$ & $5.3 \pm 0.2$ & $2.8 \pm 0.1$ & 35 \\
Pre-CPB & $30 \pm 2^{*}$ & $4.8 \pm 0.2$ & $2.5 \pm 0.1^{*}$ & 35 \\
$5 \min$ ON & $19 \pm 1^{*}$ & $3.4 \pm 0.1^{*}$ & $1.9 \pm 0.1$ & $33 \pm 0.2^{*}$ \\
$30 \min$ ON & $20 \pm 1^{*}$ & $3.8 \pm 0.3$ & $2.1 \pm 0.1$ & $29 \pm 1^{*}$ \\
$45 \min \mathrm{OH}$ & - & - & - & $27 \pm 1^{*}$ \\
$90 \mathrm{~min}$ ON & $22 \pm 1^{*}$ & $3.1 \pm 0.4^{*}$ & $2.3 \pm 0.4$ & $34 \pm 2$ \\
\hline
\end{tabular}

$*=p \leq 0.05$ from $C$. 
changes because of haemodilution, decreased protein binding and reduced peripheral perfusion. Also, the clearance of most drugs is reduced secondary to reduced hepatic metabolism and/or renal excretion.

The effects of CPB on the pharmacokinetics of anesthetic agents have been described for fentanyl. Bovill and Sebel ${ }^{5}$ found a large variability in the plasma levels measured in their patients. Within 5 min of initiation of $\mathrm{CPB}$, the plasma concentration of fentanyl had decreased by 53 per cent. This decrease in fentanyl plasma levels went beyond the expected effect of haemodilution ( 41 per cent fall in haematocrit). The authors concluded that tissue redistribution was therefore increased, probably because the free fraction of fentanyl had increased. There was no obvious pattern of changes in plasma levels. Koska, Romagnoli and Kramer ${ }^{6}$ found that the elimination half-life of fentanyl after CPB was greater than in nonCPB patients. They ascribed this difference to the effects of CPB on hepalie blood flow, which decreased by 30 per cent during $\mathrm{CPB}$. Thus, the institution of $\mathrm{CPB}$ causes significant perturbations of drug homeostasis so that the maintenance of stable plasma levels of drugs is very difficult using routine administration schemes. Moldenhauer and $\mathrm{Hug}^{\top}$ compared a manual continuous infusion of fentanyl to the traditional single bolus technique. Both methods were unable to provide stable plasma levels of fentanyl before as well as during CPB.

The ability of a pharmacokinetically driven CACI to attain and maintain steady state plasma levels of various anaesthetic drugs during cardiac surgery, but not on CPB, has been shown previously. ${ }^{1}$ The question our investigation sought to answer was whether the use of an infusion scheme based on a pharmacokinetics model which employed parameters derived from a population of healthy rormothermic surgical patients could allow the clinician to achieve and maintain predictable plasma levels of sufentanil in cardiac surgical patients during hypothermic CPB.

The results of this investigation show that $\mathrm{CACI}$ was able to attain and maintain stable plasma levels of sufentanil prior to and during CPB. The discrepancy between the set point and pre-CPB sufentanil plasma levels is possibly due to an underestimation of the volume of the central compartment $(\mathrm{Vc})$ in the infusion equation: an error of similar magnitude but opposite direction was reported in a previous study in non-cardiac patients. ${ }^{8}$ The initiation of CPB caused a minimal decrease $(<20$ per cent) in plasma levels in spite of a larger degree of haemodilution as evidenced by the decrease in haematocrit ( 37 per cent) and protein ( 29 per cent) levels. It is likely that the effect of haemodilution was partially countered by the redistribution of free drug from the tissues to the blood stream. ${ }^{4}$ However, since the volume of distribution (Vd) of sufentanil is large $\left(2.86 \pm 0.25 \mathrm{~L} \cdot \mathrm{kg}^{-1}\right)$ and the priming volume of the cardiopulmonary bypass pump ranges between 1500 and $2000 \mathrm{ml}$, the effect of haemodilution on plasma levels would be expected to be minimal. The initial decrease was temporary as the plasma levels of sufentanil increased over time because of redistribution of free drug from tissue to plasma and as the infusion regimen continued. These data imply accumulation of sufentanil under the conditions of this study. It should be noted that, as the concentration of sufentanil was increasing during CPB, the infusion rate of sufentanil was not constant, but was decreasing in an exponential fashion.' The inverse rejationship found between plasma levels and both nasopharyngeal temperature, closely reflecting liver and metabolic reaction temperatures, and inflow temperature, which determines rate and direction of thermal changes during CPB, supports the hypothesis that hypothermia is a major cause of the accumulation of sufentanil, possibly through inhibition of hepatic drug metabolism and hepatic blood flow. In conclusion, our results show that our CACI system is able to achieve and maintain within close range stable plasma levels of sufentanil before and during hypothermic CPB, using pharmacokinetic parameters derived from healthy, normothermic patients not on CPB. However, sufentanil accumulates when infused during CPB, suggesting that the kinetic parameters from healthy normothermic patients are not entirely appropriate when used to design an infusion scheme during hypothermic CPB.

\section{References}

1 Alvis $\sqrt{ } M$, Reves $J G$, Gavier AV et al. Computerassisted continuous infusion of fentanyl during cardiac anesthesia: comparison with a manual method. Anesthesiology $1985 ; 63 ; 41$.

2 Michiels $M$, Hendriks $R$, Heykants $J$. Radioimmunoassay of new opiate analgesics alfentanil and sufentanil. Pharmacakinetic profile in man. J Pharm Pharmacol 1983; $35: 86$.

3 Bowill JG, Sebel PS, Blackburn CL, Oei-Lim V, Heykants $J$ J. The pharmacokinetics of sufentanil in surgical patients. Anesthesiology 1984; 61: 502.

4 Holley FO, Ponganis KV, Stanski DR. Effect of cardiopulmonary bypass on the pharmacokinetics of drugs. Clin Pharmacokinet 1982; 7: 234.

5 Bovill JG, Sebel PS. Phamacokinetics of high-dose fentanyl. Br J Anaesth 1980; 52: 795.

6 Koska AJ, Romagnoli A, Kramer WG. Effect of cardiopulmonary bypass on fentanyl distribution and elimination. Clin Pharmacol Ther 1980; 29: 100. 
7 Moldenhauer CC, $\mathrm{Hug}$ CC. Continuous infusion of fentanyl for cardiac surgery (Abstract). Anesth Analg 1982; 61: 206

8 Vinik HR, Gelman S, Proctor J, Halpern NB. Computerizeil infusion of sufentanil: a comparison of morbidly abese and nonobesc patients (Abstract). Aresth Analg 1986; 65: \$161.

\section{Résumé}

Afin d'examiner l'habileté que possède un système d'infusion continue assisté par ordinateur (ICAO) à maintenir des niveas plasmatiques constants de sufentanil durant ia circulation extracorporelle (CEC), on a anesthesié dix patients avec du diazépam, de l'enfiurane at de I'oxygène jusqu'd ce qu'il se reste que dix minutes avant le début de la CEC. A ce moment, une infusion de sufentanil (dont on avait déterminé la vitesse d'infusion en utilisant les données pharmacocinétiques provenant de patients chirurgicaux en sante) qui avait pour but d'atteindre une concentration de compartiment central de $5 \mathrm{ng} \cdot \mathrm{mI}^{-1}$, a été commencée par ICAO. Les concentrations plasmatiques de sufentanil, l' hématocrite, les concentrations de protéines totales et d"albumine. la température nasophanyngienne es celle du sant à l'entrée de la CEC ont été obterues à des intervalles prédéterminés avant le début de la CEC et pour une période allant jusqu' à 90 minutes après le débur de la CEC. Les concentrations plasmatiques de sufentanil ont atteint $3.8 \pm 0.4$ $n g \cdot m l^{-1}$ avant la $C E C$ et se sont rapprochées du point visé $(4.7$ $\pm 0.4 \mathrm{ng} \cdot \mathrm{mt}^{-1}$ ) sur une période allant jusqu' à 90 minutes après le début de la CEC. En conclusion, nos résultats démontrest qu'il ext possible d'oblenir des niveaux plasmatiques stables de sufentanil sous CEC en utilisant une infusion continue basée sur la pharmacocinétique; cependant, nos données laissent entendre qu' un tel système pest mener à une accumularion de médicrments durant la CEC. 